\title{
Italian Fascism between Ideology and Spectacle
}

\author{
Federico Caprotti
}

In April 1945, a disturbing scene was played out at a petrol station in Piazzale Loreto, in central Milan. Mussolini’s body was displayed for all to see, hanging upside down, together with those of other fascists and of Claretta Petacci, his mistress. Directly, the scene showed the triumph of the partisans, whose efforts against the Nazis had greatly accelerated the liberation of the North of Italy. The Piazzale Loreto scene was both a victory sign and a reprisal. Nazis and fascists had executed various partisans and displayed their bodies in the same place earlier in the war. Indirectly, the scene was a symbolic reversal of what had until then been branded as historical certainty. Piazzale Loreto was a public urban spectacle aimed at showing the Italian people that fascism had ended. The Duce was now displayed as a gruesome symbol of defeat in the city where fascism had first developed. More than two decades of fascism were symbolically overcome through a barbaric catharsis.

The concept of spectacle has been applied to Italian fascism (Falasca-Zamponi 2000) in an attempt to conceptualize and understand the relationship between fascist ideology and its external manifestations in the public, symbolic, aesthetic, and urban spheres. This paper aims to further develop the concept of fascism as a society of spectacle by elaborating a geographical understanding of Italian fascism as a material phenomenon within modernity. Fascism is understood as an ideological construct (on which the political movement was based) which was expressed in the symbolic and aesthetic realm; its symbolism and art however are seen as having been rooted in material, historical specificity. This paper will therefore trace its understanding of spectacle to Guy Debord's (1995) ideas on the concept, and, following Walter Benjamin (1999), will argue for a consideration of fascist politics as an aesthetic politics which was nevertheless deeply embedded in ideology and the historical geography of a particular period and place. We also argue that while analysis of Italian fascism may distill salient defining characteristics which may be applicable to 'fascist' regimes elsewhere and in different historical periods, and may help to understand these regimes' use of ideology and discourse, nonetheless this analysis remains rooted in a critical consideration of Italian fascism and wary of comparative approaches. Thus, while the work of Laclau (1977) and Laclau and Mouffe (1985, 1987) are utilized because of their broadening of our understanding of the concept of hegemony, central to an understanding of authoritarian regimes worldwide, this paper is cautious of extending its scope to an offering of comparative linkages. As Laclau himself noted (see Beasley-Murray 1998), his theorizations on hegemony were generated from a consideration of the historical-geographical specificities of Peronism in Argentina. One may posit the same observation with regards to Gramsci and his embeddedness in a position of opposition in fascist Italy. The position of this paper regarding fascism and its national context in Italy can be related to Mark Bevir's (2000) idea of an "irreducible specificity of meanings", whereby ideas and words are political and cannot be read apart from their contexts. When Gramsci talks about hegemony, he is talking about a concept. When he talks about fascism, he is talking about Italian fascism.

In this paper, fascism will be interpreted as a society of spectacle based on an unstable ideological substratum. Firstly there will be an analysis of the problematic concept of fascist spectacle, based on an aesthetic form of politics, and its application to the arguments presented in this paper. Secondly, the paper will analyze the ideological roots of fascism and its particular characteristics, covering various salient and founding facets of fascist spectacle. Elite rule and the role of the leader will be discussed first of all, followed by fascism's ambiguous connection with modernity 
and modernization. Thirdly, fascism's problematic relationship with modernity and futurism will be analyzed, and the fourth characteristic to be examined will be the nationalist side of fascism. Lastly, there will be a discussion of the role of war and military metaphors in fascist aesthetic politics. All these often contradictory characteristics are seen as contributing to the composition of the collage that is fascist spectacle. They were various facets which fascism presented to the observer in its attempt to solidify itself into a congruous whole. The final section presents some conclusions.

\section{| The Spectacle of Fascism and Aesthetic Politics}

Fascism was heavily based on symbolism and myth (Falasca-Zamponi 2000). It drew on ideals of ancient Roman virtue in its aim to found a new, fascist nation which would stand head-to-head with other European powers and herald a new era. The fascist obsession with myth and symbolism could be understood in terms of fascism's attempt to represent and to conceal what Schnapp (1992a; 1992b) has termed its unstable ideological core. Fascist ideology was by no means well-defined, and attempts at delineating its boundaries are problematic. Furthermore, in order to capture Italian fascism's main reference points and characteristics, it is useful to interpret fascism so as to bring into evidence its constituent parts and their interplay. This section attempts this by interpreting fascism as a society of spectacle, as illustrated in the following:

The concept of spectacle was first developed by Guy Debord (1995) in his Society of the Spectacle . Debord notes the fact that the twentieth century saw the rise of an overwhelming form of public display, or spectacle, linked to politics. Additionally, Debord outlines his idea of spectacle in relation to the prevailing current economic system (see Marshall 1992). He moreover states that "the whole life of those societies in which modern conditions of production prevail presents itself as an immense accumulation of spectacles; all that once was directly lived has become mere representation" (Debord 1995:12). However, spectacle itself is not mere representation. It is not a collection of images, stills or pictures. Spectacle is a social relationship between people, mediated by images (Debord 1995). In this sense, it is a represented reality at the same time that it becomes reality itself, or reality as a dominant group would have it. Furthermore, it is a reified social relation. As Marx wrote in the first volume of Capital, "it is only a definite social relation between men that assumes, in their eyes, the fantastic form of a relation between things" (in LukÀcs 1967). However, the overall picture appears more complicated (Tihanov 1995). On the one hand, spectacle becomes the reification of a social relation between people; on the other, spectacle itself can be said to work towards the reification of the dominant political-ideological system, in this case fascism. Thus, spectacle-at a time of crisis of modern systems of governance and economics-becomes a tool through which stability can be reinjected into the system, albeit temporarily (Laclau 1977).

This paper interprets spectacle based on Debord's framework and coupled with Walter Benjamin's theories of aesthetic politics. A short note on Benjamin is in order here. The German thinker's ideas can be criticized for their underdevelopment, as Benjamin died before he could fully work out the intricacies of his system of thought. However, this paper treats Benjamin's ideas as extremely useful because — yet again — of their historical, geographical specificity. Benjamin lived and died plagued by thoughts of fascism and Nazism and terrorised by their real presence and evolution during his lifetime. Therefore his theories, while not as complete as would have been desirable had he survived, are extremely useful in that they are a snapshot of theorization of a political system from a particular era. They possess that sense of urgency and direction which is also witnessed, to a greater degree, in Antonio Gramsci, another victim of Europe's totalitarianisms.

Spectacle is treated in this paper as an apparent and carefully manufactured display, projecting a fetishized image of reality. The spectacular process of fetishization conceals the social relations which have enabled the production of spectacle and the commodification of the image. This may seem like a contradiction of Debord's core idea of spectacle being a social relation between people, mediated by images. However, what this paper aims to highlight is that precisely because spectacle is a social relation, or a set of social relations, it can display a transformed version of the reality in which the social relations in question exist. Thus, spectacular displays (such as newsreels, films and street scenes such as parades or mass gatherings) can be manipulated and divorced from everyday life, whilst being rooted and grounded in that life. The image of reality they project is the reified reality of fascism as a thing. This is this meaning that the word spectacle takes on when used henceforth. In this way, spectacle becomes a useful tool of analysis since it embodies relations — and tensions - within fascism which were aesthetically disguised and presented 
as something else altogether. Through spectacle, fascism ceased to be lived and became representation: the regime distanced the masses from everyday life through the presentation of an alternative reality in the image. Nevertheless, at the same time that the image mediated the construction of fascist spectacle, it became a solid commodity which can be the focus of research in that it is also a lens into the relations which produced it, and therefore into the forces at play within fascism.

Debord's concept is deeply intertwined with notions of power and the forging of a reality consonant with the world view of a certain power group, which in this paper would be identified with the fascists. The concept of spectacle has been applied to Italian fascism by sociologist Simonetta Falasca-Zamponi (2000) in her book Fascist Spectacle: the Aesthetics of Power in Mussolini's Italy. Falasca-Zamponi (2000), however, takes the concept of spectacle developed by Debord in 1967 and transcribes it unproblematized to the historical and geographical context of fascist Italy. Her book takes the word "spectacle" at face value, with little or no definition, with surprisingly little explanation of how the concept may be applied to the study of fascism. More reference to Debord would have been useful; his theory is only mentioned in a footnote. The result is that links between fascist issues outside the culturalaesthetic sphere and fascist symbols and myths are not convincingly made (Caprotti 2003). What this paper aims to expand on is the aspect of fascist spectacle which is linked to the materiality behind the production, commodification and consumption of social relations as evident through spectacle in fascist Italy.

However, Falasca-Zamponi's (2000) spectacle-based analysis is useful in that she utilizes the concept of aesthetic politics and merges it with spectacle in order to understand Italian fascism. Following on from this, aesthetic politics is understood here as the mechanism through which enabled the formation of spectacle. Falasca-Zamponi relies on Walter Benjamin's (1999) study of the aesthetic character of fascism, carried out in his 1936 essay, The Work of Art in the Age of Mechanical Reproduction. Benjamin states that artworks before the modern era possessed a mystique, described as aura, which was attributable to the aesthetic distance between the artwork and the passive audience. In the modern era however, Benjamin continues, the technological reproduction of art caused a near total loss of aura. This leads to more active audience participation, because the reproducibility of art leads the spectator to engage with the work of art: one is no longer spectating but interacting (Benjamin 1973). Benjamin believed that art, in this way, could become a focal point for social struggle. Herbert Marcuse (1998), similarly, believed that art could become an instrument of opposition as long as it represented alternative realities and was not overly alienating (1998). In the case of fascism, however, Benjamin saw that technology did not lead to a loss of aura. Writing from the bleak outlook of the 1930s, when totalitarianism and authoritarianism seemed to be unstoppable forces, Benjamin saw that technology was used to enhance the symbols and aura of the work of art and to maintain the auratic distance between the audience and the product of fascist aesthetic politics. This served both to keep the masses subdued and to help them express themselves in the required manner. Thus, in a period of modern economic and political-ideological crisis, fascism responded by harnessing modernity to build hegemony. Benjamin argued that the process through which aura was reinstated caused aesthetics to be injected into politics, as political power aimed to become transcendent in the eye of the masses. Transcendence effectively liberated the fascist regime from grounded democratic responsibility in the political process. As stated by Falasca-Zamponi (2000):

The notion of aesthetic politics will further illuminate the shady links between fascism's belief in the leader's omnipotence and its conception of the "masses" as object, between the artistic ideal of harmonic relations and the auratic embracement of war, between the construction of "new men" and the focus on style, between the reliance on spectacle and the attack on consumption, between claims to the spiritual functions of the state and the affirmation of totalitarianism. (P. 8)

Aesthetic politics has two consequences, according to Benjamin. First, it becomes an end unto itself. Thus, totalizing aims can be pursued without objections from tradition, laws, and ethics. Fascism could be seen as utiliizng this form of politics in order to pursue its goal of a totalitarian nation. The second consequence is war. This is because only war can give the masses an aim whilst preventing them from seeing and turning against an established order (Falasca-Zamponi 2000). This point will be analyzed in greater detail in the following.

The coupling of politics and aesthetics can be seen as the result of a particular historical process (FalascaZamponi 2000; Gilbert 1972; Tatarkiewic 1980). The path of aesthetics before its intertwining with art and politics can be traced as a precursor to the analysis of aesthetic politics (Falasca-Zamponi 2000). Originally,

aesthetics was mainly confined to the study of nature: aisthitikos in Greek signified perception through feeling. Aesthetics was based on the human experience of the world. From the eighteenth century onwards, however, aesthetics was incorporated as a discipline within western philosophy. During the Enlightenment it became concerned with the 
study of cultural objects, which were by then being produced en masse through increasingly available techniques of reproduction. Aesthetics entered the realm of art, as nature was replaced by artificial objects as the discipline's main focus: One critic argues that aesthetics "born as a discourse of the body that would complement the philosophy of the mind, aesthetics turned the natural into its opposite - an intellectual object" (Falasca-Zamponi 2000:11). Art had until then been largely dedicated to representing humans and their expressions and desires. However, a split arose within art as modern artists increasingly decided to isolate and abstract themselves from the realm of the senses and from nature (Eagleton 1990). The idea of independent creation, or autogenesis, entered the artistic scene. The artist was no longer seen as a mirror of reality but as a creator of realities.

The idea of autogenesis can shed some light on certain issues connected with fascism's modernity and its reliance on the figurehead of Mussolini. Autogenesis has been seen as a modern response to a problematic relationship between culture and nature, whereby the culture/nature dualism leads to other problematic relationships such as the ones between public and private, active and passive, and the like (Falasca-Zamponi 2000). Cornelia Klinger believes that this leads to a polarization through which gender takes centre stage, as rational man, identified with culture, attempts to dominate an irrational, sensual, womanly, nature. The concept of autogenesis springs from the belief that in order to achieve freedom, man must overcome nature and its laws and limits: the promethean project of modernity. The Enlightenment ideals of self-emancipation and emancipation from material wants and needs have been identified as central to this project, an effort to overcome nature (Harvey 1996; Stokes 1998). Hence, FalascaZamponi (2000) believes that the concept of the domination of a womanly nature is crucial to an understanding of fascist aesthetic politics and some of its ideals. The relationship between aesthetics and the senses leads the author to an analysis of the subsequent alienation of sensual life under fascism. Mussolini can be seen as the conceptual, autogenetic artist-creator shaping the Italian masses, even though Barbara Spackman (1996) has noted that Walter Benjamin's (1999) understanding of fascism can be understood as a gendered account, participating in the fascist rhetoric of virility through its focus on the salvation of the masses from fascism. However, as seen above, technology was utilized by fascism in order to recreate the auratic distance between the work of art and the audience. In the case of Italian fascism, the autogenetic artist-creator can be seen as having aimed specifically at alienating the audience's critical capabilities and influencing it without the threat of being critically challenged.

Benjamin (1973) stated that alienation of the senses resulted from the onslaught of modernity. Bombarded and overwhelmed by images and sounds, the Modern Man (sic) resorted to defending himself through an internal "anaesthetic" procedure. The senses were repressed. According to Benjamin, sensory overload and subsequent alienation was a characteristic endemic not only to fascism but to the whole of modernity. However, fascism is seen as exploiting modern contradictions by trying to compensate for the loss of meaning resulting from "anaesthetization": desensitization opens a crack in perception which can be widened and filled by spectacle. Other modern contradictions (such as modernity's contradictory stance towards nature and tradition) will be analyzed further on. It must be noted, however, that fascism embodied and expressed in its own particular manner-contradictions which characterized the whole of modernity, and which can therefore arguably be found expressed in similar systems elsewhere, whether in Peron's Argentina or the modern-day People's Republic of China, where the organization of spectacle for a billion people is vastly sophisticated.

Within Italian fascism, spectacle was based on the use of a highly aestheticized form of politics. The injection of aesthetics into politics enabled the image, with its illusions and concealed production, to enter the political realm. The tensions within fascism were concealed (partially at least) and the public's attention directed elsewhere, through the employment of overwhelming visual, auditory and sensory displays and persuasion which concealed their own motivations and production and which fetishized the image above the material. Aesthetic overproduction led fascist politics to become an aesthetic politics. This was aimed at the creation and maintenance of spectacle as a means for control and as a means to represent itself as free of contradictions. As Falasca-Zamponi (2000) notes:

I would like to stress Benjamin's point further and add that fascism actively strove to impel and actuate sensory alienation. In a time of new technologies, filmic panoramas, dioramas, and world exhibitions, fascism offered a phantasmagoria of rituals and symbols [...] flooding the senses. With photographic images and newsreels, appearances on airplanes and motorbikes, and speeches from balconies and extravagant podiums, Mussolini dominated the fascist spectacle. (P. 13)

Mabel Berezin (1997) points out that a clear focus on spectacle can be identified within fascism after its rise to power in 1922. Spectacle became the created reality through which fascist aesthetic politics worked and beneath which lay a reality of contradictions and problematic relationships. Berezin’s (1997) focus on the year 1922 as a 
grounding point in the general discussion on aesthetics and spectacle with reference to Italian fascism is decidedly useful in that it locates a more general discussion on aesthetics within the context of the history of Italian fascism. However, she separates spectacle and aesthetics by stating that the former replaced the latter and became the main force in fascist popular cultural initiatives after 1922. The separation of spectacle and aesthetics she proposes does not seem convincing, even though it may be achieved in a conceptual sense. Furthermore, Berezin does not qualify her understanding of spectacle sufficiently. Therefore the links between aesthetics and spectacle are not clear in her account, with spectacle seemingly falling within the broader field of aesthetics.

\section{Fascism's Unstable Ideology: Ideology, Elites and Illusion}

Fascist ideology is a highly contested terrain of enquiry. Paxton (1998) has highlighted that the character and ideological bases of Italian fascism, and indeed of fascism in general, are hard to define. The boundaries of fascism are ambiguous in both space and time. He points out that fascist regimes develop temporally and their early stages might be a poor indication as to their subsequent direction. It is also difficult to define fascism spatially, although this point gives us a clue as to its relevance, since fascist modes of government are not spatially or temporally confined to a certain period or place. For example, various states in the twentieth and twenty-first centuries, from Russia under Stalin, to 1930s Japan, to Iraq under Saddam Hussein, have been described as "fascist" (Paxton 1998). An understanding of the ideological bases of Italian fascism is crucial to an understanding of the regime as a whole. Examining totalitarian regimes, Juan Linz (2000) has highlighted the need for an analysis of ideology: “The capacity for deception and temptation by totalitarianism is only equalled by its tragic legacy. Only work focusing [...] on the ideological dimension of totalitarianism, as seen sometimes in films, newsreels, and literature, can capture the basis for the political institutions [of totalitarian regimes]" (p. 16-17). Ideology can be utilized as the starting point for an understanding of particular systems of governance and the societal systems they attempt to engineer (Sutherland 2005). In addition, many critics have argued that world-views are implicitly ideological, and even more so when concerned with the production of 'Grand Discourses' which, as in fascism, contribute to the manufacture of consent (thus becoming a more desirable route to hegemony than coercion) (Laclau and Mouffe 1985, 1987; Martin 2002). Italy was the first state to define itself as fascist. It will be useful to discover the ideological roots which contributed to the development of the movement.

The difficulty of defining fascist ideology is augmented by the fact that ideology itself is a concept which has taken on various meanings through time. It is a power-charged concept. As a term, it is seen as deriving from the age of the French revolution, although it underwent a variety of shifts in meaning up to the fascist era. It was initially conceived by Enlightenment philosophe Antoine Louis Claude Destutt, Comte de Tracy (1754-1836), during the "wild revolutionary decade" of the French revolution (Carver 1991). It was utilized to describe enlightened rule by an intellectual elite. The assumption was that intellectuals would discover the truth and governments and political authorities would implement policies based on it. It can be seen that from the start, ideology was a term closely associated with the leadership and intellectual activities of a particular elite (Duncan and Duncan 1992). The ideological element constituted by elite rule was later appropriated by Karl Marx, who provided an alternative definition. The ruling class was identified as creating ideologies that served the purpose of particular classes or individuals. Ideologies were thus interpreted as “illusions". Therefore, according to Carver (1991), "Marx's analysis ideology came to mean not just a body of ideas that conformed to certain formal characteristics, such as those of de Tracy's system, but any ideas, however unsophisticated, that gave apparent validity and assumed authority to the claims that members of different classes might make when they pursued their various interests” (p. 7). In Marx's view, ideologies could be reactionary, conservative, reformist or revolutionary, depending on how material interests were pursued and, once gained, protected (Eagleton 1990).

Fascists liked to portray themselves and their ideology as revolutionary. Their coming to power was mythically depicted as a revolutionary event. Fascism gained power on October 30, 1922, the day on which Mussolini became prime minister of Italy. This event had been precipitated by fascist Blackshirts, mobilizing and marching on Rome on October 27 (giving rise to the infamous "March on Rome"). This caused liberal Prime Minister Luigi Facta to declare martial law in the capital and to summon Mussolini to Rome on October 28. Eventually, the Blackshirts paraded through Rome on October 31, with few fatal and violent episodes. Fascism had gained power relatively peacefully and the March on Rome was but a coda to the whole affair. It was subsequently portrayed, however, as a 
revolutionary takeover of power led by Mussolini. Later on, illusion became part of fascist reality as October 29 and was instituted (starting from 1927) as Day 1 of Year 1 of the fascist era (Falasca-Zamponi 2000; Payne 1995). This example illustrates the fact that fascist ideology can be seen as a reinterpretation of reality, aimed at supporting the rule of an elite, led by a leader. Representations of national history became part of the spectacle of fascism as illusion was translated into literal reality. As one critic has noted "tapping away at nationalism in this way is rather like cracking open an egg; the outer shell of rhetoric surrounds the ideological core” (Sutherland 2005:185).

Political reliance on elites is by no means a phenomenon restricted to fascism. Having said this, the conceptual development of the role of elites from the Enlightenment onwards influenced Italian fascism in a significant manner. The Enlightenment celebrated reason and science above traditional monarchic or religious authorities. Liberal ideology also came to the fore during this period. It was based on individualism, a limited state and an essentially laissez-faire economy. Fascism was opposed to liberalism. It saw it as a force leading to the pursuit of monetary wealth as its own end, class divisions and a separation between the state and citizens. The fascists pursued a more totalizing unity within the state, extending to economic activity as well as citizenship. However, Italian fascism absorbed certain Enlightenment ideas (Eatwell 1996). First of all, it incorporated the view that violence could be necessary to purge an existing order. We would add that in this respect the fascists were probably more influenced by the futurists, who saw violence and war as a social necessity[1]. Secondly, fascists accepted the idea that the will of the people could only be expressed when incorporated into a mass-based politics.

Fascism was also influenced by ideas developed during Romanticism, which originated in the eighteenth century onwards and was seen as a reaction against the Enlightenment (Eatwell 1996). Four Romantic ideas in particular were integrated into fascism. The first of these was the worship of nature. The second was hostility towards material values. Thirdly, fascism was influenced by the exaltation of genius over the mediocrity of the masses, leading to the concept of a national leader (Mussolini) who could engineer a national rebirth. Lastly, fascism took on board the glorification of the national over the universal and timeless. This Romantic idea contributed to the age of nationalism, which played a great part in the formation of Italy and the whole of modern Europe. Finally, Mussolini, initially an orthodox Marxist (Payne 1995), was also highly influenced by Marxist ideas of struggle as the means for societal development, and possibly combined this with his more nationalist ideas. Fascist struggle was supposed to be violent, revolutionary and composed of masses led by a dominating figure. Mussolini utilized the ideas elaborated by elite theorists, such as Vilfredo Pareto and Robert Michels, the former Italian and the latter German. Nietzsche's philosophical idea of the "Superman" as a will-based great leader of men who would turn politics into aesthetics probably also influenced Mussolini (Eatwell 1996).

Elite rule in Italian fascism was embodied, on the surface at least, by Mussolini, who was represented as the incorporation of the ideals and principles of fascism. This gave fascism a useful starting point for the exercise of authority. Ruling elites justify their decisions and aims through recourse to a myth of official "ideology" (Lasswell 1966). Elites attempt to propagate a homogenous power-based perspective based on political myth. This myth is identified through an official doctrine (assumptions about political goals and justifications of public policy) and a formula, constituted by expectations about courses of action which are authoritatively enforced (Lasswell 1966). To this we would add another characteristic of elite rule under fascism, namely the rejection of a counterideology. Mussolini, for example, portrayed liberalism as the opposite of fascism. The identification of an inimical 'Other' has been shown to be a crucial characteristic of populist regimes : in this case we are referring to ideological 'Others', but obvious examples can also be seen in Italy's foreign policy towards Africa and its antagonism towards Europe's established powers (Laclau 1977).

Mussolini was often represented as a leader of masses, embodying "virile" qualities (Falasca-Zamponi 2000). It is interesting to note that in the case of fascism, the study of elite rule highlights the conceptual contrast between a male leader and the masses which were represented as embodying female characteristics. This elitist conception is examined by Falasca-Zamponi as being rooted in mass-psychology and crowd-psychology theories elaborated at the turn of the twentieth century by the likes of Gaetano Mosca, Vilfredo Pareto, Gabriel Tarde, Gustave Le Bon, Robert Michels, and others[2]. Masses had been a focus for social analysis in France in the second half of the nineteenth century. At this time, uncertainty over the development of an industrial, urban-based society was coupled with a fear of the crowd as mass protests and strikes began to come to the fore. Crowds were seen in terms of irrationality and potential for criminal action, a concept which can still be seen today in urban geographical analysis of, for example, the use of CCTV footage as means of social control of public space in the city (Toon 2000). The importance of the urban sphere as a focus of late nineteenth century fear and power struggles is also noted by Ghirardo and 
Forster (1985). Gustave Le Bon, exemplifying the concerns of the time, published his book The Psychology of Crowds (La Psychologie Des Foules) in 1895. The book characterized crowds and the masses as inferior forms of evolution, exemplified by children, women and savages (Falasca-Zamponi 2000). As a result, masses (and women, by association) were "scientifically" judged to be unfit for participation in the political process. These discourses were appropriated by Italian fascism.

Mussolini was aware of Le Bon's arguments (Eatwell 1996), which drew on the theory of cells. This stated that, during the process of evolution, the passage from monocellular to pluricellular life forms carries with it a risk of decomposition of the organism (in this case, the state). The transition is rendered possible through the coordination of cells. This point was translated into the need for a political leader to shape and direct the masses and organize the state apparatus, which would otherwise decompose into a decadent society. The leader needed to be male since women were identified with the masses. Women's subordination was therefore justified by the social application of a biological theory. Since masses were supposedly governed by emotions, a further corollary highlighted by FalascaZamponi (2000) is that the leader needed to communicate to the masses through myths and images, appealing to their emotions but not to their reason. Thus, Mussolini became the artist trying to plasmate the inert masses. Elite rule and identification of ideology and political direction with an artist-politician gave rise to the creation of illusions based on an official (albeit shifting and not fully codified in the case of Italian fascism until 1932) ideology constructed from centuries-old ideological roots. The ideological roots of fascism can be seen as being the building blocks for the stage on which fascism constructed and represented itself. These roots, and their consequences, will be further explored in the next section, which analyses the relationship between fascism, modernity and modernization on the one hand, and between fascism and futurism on the other.

\section{Fascism, Modernity and Modernization}

A characteristic of Italian fascism was its contradictory stance towards modernization. Fascism attempted to retain the benefits of modern technology and science whilst renouncing "modern" values and trying to hark back to "Roman" values. Fascist ideology reflected this tension between embracing modernity with its onslaught of technological, industrial, and social modernization, and the espoused need to rekindle traditional values. Spectacle was utilized to reconcile the tension between embracing and rejecting modernity and its products: the image was utilized to gloss over the underlying, problematic relationships which contributed to its construction and production.

Modernity, a Western European concept, is seen as a reaction to what existed before (Harvey 1990), namely the medieval and preindustrial era. Modernity, the full meaning of which cannot be explored here, is understood in this paper as the historical era which started in the western world with the Enlightenment. Part of its philosophical basis was closely connected with the idea that destiny can be shaped and is not simply determined by outside forces (Eatwell 1996). In a reaction to a medieval, theological world-view which saw man as reacting to divine and natural forces, modernity placed man in an anthropocentric universe of experience where potential achievements were attainable through progress. Progress was in turn predicated on objective and positivist science leading to technological advances, in a process of modernization. The process was not limited to science: progressive ideas were intermeshed with politics and society, as desirable sociopolitical goals became seen as attainable through modernizing the political process. It could be argued that this was the case with nationalism and the idea of nation, especially after the Congress of Vienna in 1821 and the European uprisings of 1848, which projected progressive nationalist ideas into the popular sphere.

Modernization was also seen by the fascist regime as useful for the construction of a nation. In a 1932 article published on the Enciclopedia Italiana under Mussolini's name but written by various pro-fascist philosophers, a totalizing view of the nation was crystallized in the statement that "outside the State there can be neither individuals nor groups (political parties, associations, syndicates, classes)" (1991:290). Modernization was accepted as long as it could be bent towards fascist aims. Mussolini could be seen as a man inextricably linked to the modern era, a Faustian "Developer" in Marshall Berman's (1999) terms, aiming to turn Italy into a vast construction site. Berman talks about the modern "Developer" as a person aiming to fulfil the large-scale project of modernity by wiping the historical slate clean. The fascist regime pursued its own 'creative destruction' too, but it relied heavily on the past in order to justify the policies that led to modernization and that nourished future aspirations.

Fascism's self-representation as a regime steeped in Roman ideology and classical values never totally shook off the lingering threads of its modernizing initiatives. Mussolini founded fascism in a profoundly modern and very urban geographical context. Italian fascism was founded in Milan, Italy's major industrial city, and its first struggles 
were carried out on city streets and piazzas. Many of fascism's projects and achievements reflect the fact that it viewed modern industry and technology positively, as long as they could be employed as instruments for the attainment of national and personal development. This fact has historical roots, namely in the fact that modernization was seen as a tool for building a strong Italian economy to rival those of France and Britain. Joes (1977) relates this fact to the wish for prestige on the international stage after Italy's severe disappointment with the reparations and territorial gains afforded it by the post-First World War Treaty of Versailles in 1919, which was widely seen as not recognizing the blood sacrifice of one million casualties which Italy had contributed to come to Britain and France's aid.

Fascism's positive stance towards modernization is exemplified by various projects and initiatives. For example, the fascist regime was responsible for electrification, railway expansion and land reclamation. These initiatives were often shrouded in references to Italy's Roman past. The modernizing influence of the regime can also be seen by the fact that the proportion of population employed in farming and related activities fell below 50\% for the first time in 1936 (Joes 1977). From 1932 onwards the fascist government also sanctioned the founding of several new towns in Italy. Ghirardo and Forster (1985), commenting on this, believe that the foundation of new towns could be seen as an integral part of a political program aimed at bringing Italy up to an equal or superior level in comparison with other industrialized countries. To make the point clear, Gregor commenting on modernization, stated that "Italian fascism, no matter what else it was, seems to have been an industrializing and modernizing political movement in both performance and intention. The fact that even the more orthodox Marxists are prepared to grant as much is instructive" (in Joes 1977 264).

In short, there is as much room for ambiguity in Italian fascism, as within modernity itself. Classical-leaning rhetoric and the concept of Romano-fascist values (the concept of romanit technology, science and industry. In fascism - in its motorways, factories, New Towns, land reclamation worksone can see a modern core through the shroud of rhetoric and spectacle. Utilizing Berman's (1999) description of modernity and applying it to Italian fascism, we could state that fascist modernity was composed of "brilliant designs, glamorous spectacles, so dazzling that they can blind even the most incisive self to the radiance of its own darker life within" (p. 138).

\section{Modernity, Futurism and Fascism}

Modernism was the cultural and artistic expression of the modern era. It encompassed fields as disparate as art, architecture, film, philosophy and politics. The role of modernism and futurism within fascism exemplifies the particular ideological relations which constituted Italian fascism from more general roots. It is seen as having some of its origins, in the Italian context, in the political culture of the Post-Risorgimento period, and particularly in the Italy of Giolitti. This period was crucial to the development of the avant-garde modernist movement (Adamson 1990), constituted by those European intellectuals who were imbued with typically modernist ideas of "cultural regeneration" in the period from 1900 to 1914, although similar modern ideas can be argued to have lasted to the present day. Regeneration was viewed as realizable through the constitution (or imposition) of a new set of values. Italian modernists did not limit themselves to the academic platform afforded by their most prominent, Florencebased journal, La Voce. They were prone to propagating their ideas at public events. Fascists noted the use of public space as an area for spectacle.

The vociferous futurists certainly influenced fascism in its early stages. Led by Filippo Tommaso Marinetti and based in Milan, futurists focused on the ideal of a violent, dynamic break with decadent "modern" society. They glorified war and its "purifying", regenerative qualities. Futurists also saw dynamic movement and technology as central to the constitution of a new society. In the first futurist manifesto, originally published in Le Figaro in February 1909, Marinetti (1973) laid out the key futurist beliefs: "We will glorify war—the world's only hygienemilitarism, patriotism, the destructive gesture of freedom-bringers, beautiful ideas worth dying for, and scorn for woman" (p. 22). Fascists were heavily influenced, at least at first, by futurist ideals. However, futurism lost drive after several of its founding members were killed whilst finding out what their ideals actually meant in the company of common infantry being slaughtered on the Alpine front in World War I. Antonio Gramsci (1982), one of Italy's most eminent intellectuals and a prominent communist antifascist, called Marinetti and the Futurists a "gang of screaming monkeys", arguing that futurism was in fact a rather unoriginal reelaboration of liberal beliefs (p. 749).

Modernism's influence lasted into the 1930s, even though many Italian modernists did not support fascism 
(Adamson 1990). For example, many of the urban plans developed for new towns in Italy in the 1930s were modernist, rationalist and functionalist (Benevolo 1971). Fascists also retained the Vocean modernist convictions that industrialism and technology were to be used, but that positivism, seen as sterile and alienating, should be cast out and disconnected from the utilization of science and technological advances.

Within fascism, preindustrial social practices were to be combined with modern technology and industry (Adamson 1990). Moore (1971) has noted that this illustrates an attempt at modernization without changing Italy's social structure. Additionally, Schnapp (1992a) has noted that Italian fascism's frequent recourse to Greco-Roman, classical and neoclassical metaphors and myths in the late 1930s hides the fact that Mussolini, as head of state, was identified with modern characteristics as well as classical ones. For example, newsreels often pictured Mussolini arriving at public events in motorcades, or ploughing fields with the latest Fiat tractors, thus showing the attempted fusion of modern means with preindustrial values of rural life. Adamson (1990), furthermore, has gone as far as to claim that fascism could be seen as the "politicization of Italian modernism" (p. 360).

Barrington Moore (1971) underlines fascism's contradictory constituent qualities by defining it as the consequence of “conservative modernization". Modernists and futurists coexisted in what Adamson (1990) describes as fascism's often contradictory ideological whole. An example of this contradictory whole is the following, and the reader is advised to consult the accompanying figure whilst reading what follows. Within fascism, many modernist thinkers, artists and architects were part of an antipositivist, spiritualist camp they shared with idealists, who were interested in a more comprehensive view of society which united theory to pragmatic reality. However, fascism also accommodated syndicalists, ex-syndicalists and nationalists, who were essentially positivist and materialist. The contradictions and problematic relationships deepen when it is considered that the antipositivist modernists were "revolutionary" and aggressive, like the positivist syndicalist camp. On the other hand, the idealists, in the antipositivist camp, were rather conservative. This was also the case with the nationalists, especially members of Enrico Corradini's Italian Nationalist Association (Adamson 1990). Furthermore, whilst fascism drew on modernism and futurism, these two schools of thought were not necessarily at ease with one another. For example, one of Italy's most prominent futurist architects, commenting on modern architecture, stated that it was "a moronic mixture of the most various stylistic elements used to mask the skeletons of modern houses" and grouped modern and neoclassical art together under the description of "architectonic prostitutions" .(Sant'Elia 1914, in Sant'Elia 1973:160). These examples reveal why scholars of Italian fascism tend to tread carefully in what is essentially an ideological mess.

\section{Nationalism and National Identity}

The fourth characteristic of fascist ideology discussed here is the recourse to ideals of national identity and unity. The concept of national identity has to be grounded in the particular historical conditions that gave rise to fascism in Italy. This is in order to understand how a general concept (which has had worldwide impact) can influence a particular moment in history, pertaining to a specific regime.

Italy was unified in 1861 after the struggle of national unification called the Risorgimento. However, whilst the country was unified under a single monarchy and parliamentary system, there was no corresponding movement of social unification (Guidetti 1983). This resulted in a state divided along various planes. Gramsci, for instance, identified differences within Italy which were (and still are) crucial to an understanding of its heterogeneity. These differences originate from regionalism, the difference between North and South, and the strong sense of independence of each town and city within its borders (Guidetti 1983). Perhaps this was to be expected in a country which had been composed of various different states, such as the Papal States, independent kingdoms (such as Savoy) and dependent lands such as those under the control of the Spanish Bourbons in the South of Italy and the Austro-Hungarian Empire in the North. However, the liberal elites which governed Italy after unification, influenced by the echoes of the Risorgimento and of the nationalist disorders of 1848, tried to build a sense of nation and national identity. This project saw the discursive enhancement and heroic representation of various leading figures in Italy's path towards unification (figures such as Cavour, Mazzini and Garibaldi). These personages were utilized to instil a sense of national identity and to paint the Risorgimento in more nationalist terms. Italian reality and nationalist myth jostled for space in Italy's post-unification political and social landscape (Guidetti 1983).

The roots of nationalism and nationalist rhetoric in Italy during fascism were not exclusively confined to the fascist regime itself. Even though it is often clouded in primordialist rhetoric, nationalism is a modern phenomenon (Levinger and Lytle 2001). Likewise, Woolf (1996) draws on Hobsbawm and Weber to argue that national identity 
arises through state action, even though it could be seen as the result of a process of modernization. National identity is "an abstract concept that sums up the collective expression of a subjective individual sense of belonging to a sociopolitical unit: the nation state. Nationalist rhetoric assumes not only that individuals form part of a nation $[\ldots]$ but that they identify with the territorial unity of the nation state. Such an affirmation is ideological, in that it describes as a reality an ideal relationship that nationalists wish to exist" (Woolf 1996 25-6). The interplay between myth and reality within the idea of national identity comes to the fore. This interplay, as will be argued, is crucial to an understanding of fascist ideology and spectacle.

Nationalist rhetoric, used by liberal governments, was expressed and mediated through the urban arena. For example, a dialectic between tradition and modernity is identified by Bruno Tobia (1996) in the building of urban monuments from the second half of the nineteenth century onwards to represent a symbolic construction of the nation. One of the most significant examples of this is the Vittoriano monument in Rome, a massive testament to the myth-building impetus of liberal Italy. As Atkinson and Cosgrove (1998) have noted in their geographical study, it was also an urban monument later used by Mussolini for the goal of representing fascism.

Italian fascism, much like German Nazism, attempted to construct its own reality through the institution of myths and a legendary past, "not so much to legitimize as to establish the rule of the rulers in the eyes of the subjugated" (Nolte 1971:157). Two elements of fascist ideology are combined in order to construct myth: elite rule and nationalism. In Germany, the Nazi regime made recourse to völkisch myths of ancient Germanic rurality. In Italy the mythical structure was based upon Roman values which would form and shape the fascist male. Recourse to a glorious past can be seen as part of the triadic structure of nationalist rhetoric (Levinger and Lytle 2001). A glorious past is utilized as the basis on which to form a diagnosis of ills leading to a degraded present. Degradation is characterized by various factors such as moral decline, loss of internal political unity and a decline in racial purity. A comparison of the degraded present with a glorious past is then utilized to justify a struggle against the present, in order to bring about a utopian future. These resulting tensions lead to mobilization (Levinger and Lytle 2001), and to a justification for political and social action on the part of a regime. Under fascism, the identified tensions were utilized, to a varying degree, to construct the myth of a new nation, based on new values and on will. The concept of will-based action was used as a semimythical explanation for political action.

The recourse to "will" as a catalyst for political reactions has deep roots not confined to fascism. This point was noted by Federico Chabod (1996), an antifascist academic who joined the partisan movement in Aosta during the years of Nazi occupation in Italy. He stated, in the course of a series of lectures given after the fall of the regime[3], at the University of Milan during 1943-1944, that the long transition between the eighteenth and nineteenth centuries saw a change from recourse to "judgment", to a use of "will", in justifying the making of nation-states. This is exemplified by discourses focusing on the idea of a revolutionary will. Mussolini, for example, talked about fascism's "totalitarian will" during the same speech in which he first used the term "totalitarian", during the fascist party's fourth national congress on June 22, 1925 (Falasca-Zamponi 2000:126).

As another critic, Chabod (1996), notes, national passions become such that politics start to take on an almost religious pathos (126). This was clearly the case with Italian fascism, which aimed to turn nationalism centered on fascism into a political religion, as Gentile (1996) has argued. Falasca-Zamponi, however, makes a valid point when stating that Gentile's understanding of fascism as a political religion does not fully explain fascism, even though it incorporates the appeal to nationalist symbolism in Mussolini’s Italy. In particular, Gentile's approach does not fully reconcile the multitude of problematic elements at the core of fascism (Falasca-Zamponi 2000). It could nonetheless be stated that the same point applies to Falasca-Zamponi's own account, with her exaggerated focus on overt symbolism and myths in the external characteristics of fascism clouding and enlarging the reader's view of the proportion and importance which certain displays (such as the Roman step, or passo romano) held in fascism (Caprotti 2003).

Nationalism and the idea of nation played a great part in Italian fascism's self-portrayal. They were, in fact, key components of fascism's conscious construction of spectacle, which aimed at transmitting nationalist and fascist representations of reality to a national audience. Spectacle also amplified the concept of national struggle, which will be discussed in the next section.

\section{Internal, External, Ultimate War}

Fascism was heavily influenced by war and ideas of war as a regenerating force, as we saw in the section which 
dealt with futurism. What is attempted in this section is, first of all, to reveal that Italian fascism relied heavily upon the concept of war for its construction of spectacle. The modern idea of war, linked to nation-building and seen as a tool for the resolution of internal tensions, was bent towards spectacular aims. This is because war, linked to the image in modernity through cinematography, propaganda and rhetoric, came to express struggles inherent to fascism. These struggles could only be resolved, and the regime's integrity and power base maintained, through recourse to clearly identified external or internal foes. The identified enemies of fascism, were they the Communists or the red proletariat, became "the Other" lying outside the totalitarian fascist state. This section discusses the relationship between fascism and military war (especially World War I), followed by an analysis of the conceptualization of war as an external and internal struggle aimed at creating coherence within the regime. Lastly, bellicose and military metaphors are described as forming a particular facet of fascism's spectacular self-representation.

When fascism came to power in 1922, most Italians were still heavily influenced by World War I. Over half a million men, from a population of 36 million (Keegan 1994), perished in the bloody Alpine campaigns against the Austrian and German armies. The first world war could arguably be seen as a much heavier influence than the Risorgimento on Italians and their subsequent perception of Italy, if only because it involved more people than the Risorgimento, and had a deep impact upon civilian life. For example Gramsci, in his analysis of fascism, saw World War I as a key factor. He did not attempt to view fascism as a "last stage of capitalism" and did not subtly misrepresent it, as did many of his fellow communists and Comintern writers such as Palmiro Togliatti[4]. Gramsci viewed fascism as the outcome of a specific historical and geographical process, which started mainly from World War I. He identified it as originating from the urban and later also the rural areas of Italy (Adamson 1980).

Whilst fascism was undoubtedly influenced by the irst world war, the stance of its founder towards the war was ambiguous and rooted in 1910s political uncertainty. Mussolini made much of his brief role in the trenches, glorifying the fact that he was wounded (1939). Until 1914, however, he had presented a fervently antiinterventionist façade, in line with his socialist credentials (Montanelli and Cervi 1991). The war was perhaps not so much a founding reality of fascism as was the perception that the Versailles Treaty of 1919 had not provided expected territorial gains for Italy, part of the group of nations which had "won" the war. This was not the case exclusively in Italy. John Keegan (1994), a military historian, has noted that "paramilitary parties were on the march in the 1920s, in almost every country that had undergone defeat or been cheated of its expectation of victory" (p. 367). Mussolini is described as a "voice for all those who felt that the British and French had taken an unfair share of the victor's spoils, though the Italians had made an equal blood sacrifice" (Keegan 1994:367). The leader of fascism spoke for many when he described the Versailles Treaty, Italy's weak and squabble-prone post-war liberal government and resurgent socialism as dark episodes: "I assert that the episodes of 1919 and 1920 had in them bacilli which, if not treated heroically, are deadly for the life of a civilized nation" (Mussolini 1939:65). He thought that fascism had risen to help Italy "overcome the factors of dissolution" (Mussolini 1939:66). This laid the foundations for a "revolutionary" act to save the nation. The act was the March on Rome, and as we have seen it was not revolutionary nor was it particularly violent. However, what matters in this case as in many episodes in the history of Italian fascism, is the manner in which the justification for a new political order was represented: through a metaphor of revolutionary war.

For the regime, war played an almost psychological role, in the sense that it was utilized to bind together fascism's heterogeneous and incongruous ideological mix. The fascist regime attempted to utilize metaphors of war in both an external and an internal sense so as to achieve the aim of appearing coherent. Mussolini aimed to achieve internal political conformity and acceptance. He tried to exteriorize his idea of struggle by envisaging and embarking on war against external foes. Falasca-Zamponi (2000) makes the valid point that this was an attempt to reconcile the dilemmas within fascism itself, whilst Benjamin (1999) thought that war was aimed at diverting the masses. External war can also be seen as a response to the modern juxtaposition of the processes of creation and destruction (creation of internal unity through the fictitious destruction of external "others"). Falasca-Zamponi, however, focuses too heavily on purely military conflicts (such as World War II) as examples of external war used by Italian fascism in an extreme attempt at rendering itself coherent. Furthermore, war and aggressive foreign policy have been utilized by various non-democratic or even self-defined democratic regimes throughout history in order to divert attention from pressing internal matters and conflicts. Thompson (1991) states that a corollary of violence and repression such as that used in fascist Italy is "the extent to which many post-fascist, supposedly antitotalitarian western governments have learned from, and greatly developed, the tactics, institutions and methods of control of the historically anathematised dictatorship of Mussolini” (p. 4).

Many conflicts within fascism were expressed through reference to war. These conflicts were played out in 
nonmilitary ways within national borders, and portrayed as military struggles. As such they can be described as internal wars. This is the case, for example, with initiatives such as the Battle of Wheat (the drive for demographic expansion), or the "battle" for land reclamation in the Pontine Marshes. Fascism created and externalized struggles at various levels (political, economic, social, military, and racial) so as to relieve inner tensions and create an image of political coherence. This image was created through the use of spectacle, as defined in its use to mediate fascist relations into a seemingly congruous representational whole. The concept of war was utilized within spectacle for political aims in various ways. The following examines one of the most prominent examples, the bellicose metaphor.

War and military metaphors were often used to illustrate fascism's supposed coherence. Militarism was seen as healthy by the fascists, because of the way in which it could help to regiment and shape the new fascist male which was to be fertile and devoted to the state. Various youth organizations, for example, were aimed at shaping fascist youth from an early age onwards and incorporating them into the spectacle of fascism. Their military characteristics were used as metaphors for a nation on the war path. These organizations were structured in a manner similar to the Scout movement, with hierarchies of positions aimed at creating an organized, disciplined youth society. Thus, the Balilla collected young boys who proceeded, in time, to eventually become part of the Camice Nere, or Blackshirts. This regimentation was utilized in the formation of spectacle: youth parades were organised on city streets, with youngsters wearing the symbols of fascism and marching in step. Falasca-Zamponi (2000) has examined the fact that militarism played a part in public spectacle by highlighting the invention of the Passo Romano, or Roman Step, for fascist parades. Mussolini explained the importance of militarism, taking the Passo Romano as the starting point. As stated by Mussolini in 1921:

[O]ur march...imposes individual control on everyone...impresses on everyone order and discipline. Because we want in fact to initiate a solid national discipline, because we think that without this discipline Italy cannot become the Mediterranean and world nation of which we dream. And those who reproach us for marching like the Germans should realize that it is not us who are copying from them but the Germans who copy and have copied from the Romans. Thus it is us who return to our origins, to our Roman, Latin and Mediterranean style" (in Falasca-Zamponi 2000:113-115).

The parades and public displays organized by the regime were examples of the formation of a public spectacle which was used to externalize a message of unity and common goals through recourse to military and war-oriented meaning. This type of spectacle was often found on city streets and piazzas, or represented through the media.

\section{Conclusion: Spectacular Visions}

The identification of various salient characteristics within fascist ideology is a starting point for research into fascism's aesthetic politics. The instabilities of fascism are interpreted in this paper as the raison d'être of fascist spectacle, because they were utilized to represent a coherence which is not immediately apparent in the various constituent parts and characteristics of fascist ideology and practice. Theoretical discussions on the role of spectacle can be tested against Italian fascism and the specific historical, geographical context of the development of fascist ideology. Furthermore, the construction of the spectacle by Italian fascism can be seen to have been an example of what Ernesto Laclau has described as empty signifiers. These are organizing principles with distinctive symbolic functions which embrace all meanings around a term rather than codifying a set of meanings and rejecting others (Martin, 2002). In this light, Italian fascism can be analyzed as having constructed spectacle as the shifting materialization of social relations, whereby fascism — through spectacle-came to mean different things to different audiences. This may be an obvious point. However, it is a key point when considering the consensus that Italian fascism managed to construct and maintain throughout the 1930s: spectacle became a tool through which consensus was organized and, more importantly, through which hegemony was articulated. 


\section{Endnotes}

1. Although an endless sequence of cultural/historical
reference and counter reference, it could also be argued
that the Futurists were influenced by Enlightenment
ideas in turn.
2. As has also been noted by Williamson (1999).
3. The fascist regime had fallen, but Mussolini was at the time the head of the Salo-Republic.

4. Lecturing at the Lenin School in Moscow in 1935, Togliatti (1976) travelled very far from objective analysis when he described fascism as "the open terrorist dictatorship of the most reactionary, most chauvinistic, most imperialist elements of finance capital" (Togliatti p.1).

\section{References}

Adamson, Walter L. 1980. “Gramsci's Interpretation of Fascism.” Journal of the History of Ideas 41:615-633.

-.--. 1990. "Modernism and Fascism: the Politics of Culture in Italy, 1903-1922." The American Historical Review 95:359-390.

Allardyce, Gilbert, ed. 1971. The Place of Fascism in European History. Englewood Cliffs: U.S. Prentice Hall.

Apollonio, Umbro, ed. 1973. Futurist Manifestos. New York: The Viking Press.

Atkinson, David and Dennis Cosgrove. 1998. "Urban Rhetoric and Embodied Identities: City, Nation and Empire at the Vittorio Emanuele II Monument in Rome, 1870-1945." Annals of the Association of American Geographers 88:28-49.

Ball, Terence and Richard Dagger, eds. 1991. Ideals and Ideologies: a Reader. New York: Harper Collins.

Barnes, Trevor J. and James S. Duncan, eds. 1992. Writing Worlds: Discourse, Text and Metaphor in the Representation of Landscape. London: Routledge.

Barrington-Moore. 1971. "Fascism as the Heritage of Conservative Modernization." Pp. 127-143 in The Place of Fascism in European History, edited by Gilbert Allardyce. Englewood Cliffs, U.S: Prentice Hall.

Beasley-Murray, Jon. 1998. "Peronism and the Secret History of Cultural Studies." Cultural Critique 39:189-217.

Bell, David and Azzedine Haddour, eds. 2000. City Visions. Harlow: Pearson Education.

Benevolo, Leonardo. 1971. History of Contemporary Architecture: the Modern Movement. London: Routledge and Kegan Paul.

Benjamin, Walter. 1973. Understanding Brecht. London: NLB.

-----. 1999. Illuminations. London: Pimlico.

Berezin, Mabel. 1997. Making the Fascist Self: the Political Culture of Interwar Italy. Ithaca: Cornell University Press.

Berman, Marshall. 1999. All That Is Solid Melts Into Air: the Experience of Modernity. London: Verso.

Bevir, Mark. 2000. The Logic of the History of Ideas. Cambridge: Cambridge University Press.

Caprotti, Federico. 2003. "Review of Simonetta Falasca-Zamponi, Fascist Spectacle: The Aesthetics of Power in Mussolini's Italy.”. H-Italy: H-Net Reviews Retrieved February 8, 2005 (http:// www.hnet.msu.edu/reviews/showrev.cgi ?path $=1871810533$ 64863.)

Carver, Terrell. 1991. "Ideology: the Career of a Concept.” Pp. 4-11 in Ideals and Ideologies: a Reader, edited by T. Ball and R. Dagger. New York: Harper Collins.
Chabod, Federico. 1996. “The Idea of Nation.” Pp. 124-136 in Nationalism in Europe, 1815 to the Present: a Reader, edited by S. Woolf. London: Routledge.

Debord, Guy. 1995. The Society of the Spectacle. New York: Zone Books.

De Seta, Cesare, ed. 1985. Insediamenti e Territorio. Storia d'Italia, Annali 8. Turin: Giulio Einaudi.

Duncan, James S. and Nancy G. Duncan. 1992. "Ideology and Bliss: Roland Barthes and the Secret Histories of Landscape." Pp. 18-37 in Writing Worlds: Discourse, Text and Metaphor in the Representation of Landscape, edited by T.J. Barnes and J.S. Duncan. London: Routledge.

Eagleton, Terry. 1990. The Ideology of the Aesthetic. Oxford: Basil Blackwell.

Eatwell, Roger. 1996. Fascism: a History. London: Vintage.

Falasca-Zamponi, Simonetta. 2000. Fascist Spectacle: the Aesthetics of Power in Mussolini’s Italy. Berkeley: University of California Press.

Gentile, Emilio. 1996. The Sacralization of Politics in Fascist Italy. London: Harvard University Press.

Ghirardo, Diane and Kurt Forster. 1985. "I Modelli delle Citta' di Fondazione in Epoca Fascista." Pp. 627-975 in Insediamenti e Territorio, edited by C. De Seta. Turin: Giulio Einaudi.

Gilbert, Katherine E. 1972. A History of Esthetics. Mineola, NY: Dover Publications.

Golsan, Richard J. 1992. Fascism, Aesthetics and Culture. London: University Press of New England.

Gramsci, Antonio. 1982. Selections from the Prison Notebooks. London: Lawrence and Wishart.

Guidetti, M. 1983. Storia d'Italia e d'Europa. Il Passaggio del Secolo e la Grande Guerra: Politica, Economia, Societa. Vol. 7. Milan: Jaca Book.

Harvey, David. 1990. The Condition of Postmodernity: An Enquiry into the Origins of Cultural Change. Oxford: Basil Blackwell.

-----. 1996. Justice, Nature and the Geography of Difference. Oxford: Blackwell.

Joes, James A. 1977. "On the Modernity of Fascism: Notes From Two Worlds.” Comparative Political Studies 10:259-268.

Keegan, John 1994. A History of Warfare. London: Pimlico.

Kellner, Douglas, ed. 1998. Collected Papers of Herbert Marcuse: Technology, War and Fascism. London: Routledge.

Laclau, Ernesto. 1977. Politics and Ideology in Marxist Theory: Capitalism-Fascism- Populism. London: New Left Books.

Laclau, Ernesto and Mouffe, Chantal. 1985. Hegemony and Socialist Strategy. London: Verso. 
-----. 1987. "Post-Marxism without Apologies.” New Left Review 166:79-106

Lasswell, Harold D. 1966. "Introduction: the Study of Political Elites.” Pp. 3-28 in World Revolutionary Elites: Studies in Coercive Ideological Movements, edited by. H.D. Lasswell. and D. Lerner. Cambridge: U.S. M.I.T. Press.

Lasswell, Harold D. and Daniel Lerner, eds. 1966. World Revolutionary Elites: Studies in Coercive Ideological Movements. Cambridge, U.S.: M.I.T. Press.

Levinger, Matthew and Lytle, Paula F. 2001. "Myth and Mobilisation: the Triadic Structure of Nationalist Rethoric." Nations and Nationalism 7:175-194.

Linz, Juan J. 2000. Totalitarian and Authoritarian Regimes. Boulder, CO: Lynne Rienner Publishers.

Lukács, Georg. [1923] 1967. Reification and the Consciousness of the Proletariat. London: Merlin Press.

Marcuse, Herbert. 1998. "Some Remarks on Aragon: Art and Politics in the Totalitarian Era.” Pp. 201-214 in Collected Papers of Herbert Marcuse: Technology, War and Fascism, edited by D. Kellner. London: Routledge.

Marinetti, Filippo T. 1973. "The Founding and Manifesto of Futurism.” Pp. 19-24 in Futurist Manifestos, edited by U. Apollonio. New York: The Viking Press.

Marshall, Peter. 1992. Demanding the Impossible: A History of Anarchism. London: Fontana Press.

Martin, James. 2002. “The Political Logic of Discourse: A NeoGramscian View.” History of European Ideas 28:21-31.

Montanelli, Indro and Mario Cervi. 1991. Milano Ventesimo Secolo: Storia della Capitale Morale da Bava Beccaris alle Leghe. Milan: Biblioteca Universale Rizzoli.

Mussolini, Benito. 1939. My Autobiography. London: Hutchinson and Co.

Mussolini, Benito. 1991. “The Doctrine of Fascism.” Pp. 288-297 in Ideals and Ideologies: a Reader, edited by T. Ball and R. Carver. New York: Harper Collins.

Nolte, Ernst. 1971. "Fascism as Antimodernist Revolt.” Pp. 144-161 in The Place of Fascism in European History, edited by G. Allardyce.Englewood Cliffs, U.S.: Prentice Hall.

Paxton, Robert O. 1998. “The Five Stages of Fascism.” The Journal of Modern History 70:1-23.

Payne, Stanley G. 1995. A History of Fascism, 1914-1945. London: UCL Press.
Sant'Elia, Antonio. 1973. "Manifesto of Futurist Architecture 1914." Pp. 160-172 in Futurist Manifestos, edited by U. Apollonio.New York: The Viking Press.

Schnapp, Jeffrey T. 1992a. "Heads of State". Art Issues (24):23-28.

-.--.. 1992b. "Epic Demonstrations: Fascist Modernity and the 1932 Exhibition of the Fascist Revolution." Pp.34-62 in Fascism, Aesthetics and Culture,edited by R. Golsan. London: University Press of New England.

Spackman, Barbara. 1996. Fascist Virilities: Rhetoric, Ideology, and Social Fantasy in Italy. Minneapolis: University of Minnesota Press.

Stokes, Geoffrey. 1998. Popper: Philosophy, Politics and Scientific Method. Cambridge: Polity Press.

Sutherland, Claire. 2005. "Nation-Building Through Discourse Theory." Nations and Nationalism 11:185-202.

Tatarkiewicz, Wladislaw. 1980. A History of Six Ideas: An Essay in Aesthetics. Berlin: Kluwer Academic Publishers.

Thompson, Doug. 1991. State Control in Fascist Italy: Culture and Conformity, 1925-43. Manchester: Manchester University Press.

Tihanov, Galin. 1995. "Reification and Dialogue: Aspects of the Theory of Culture in Lukács and Bakhtin." Sheffield: The Bakhtin Centre Papers.

Tobia, Bruno. 1996. "Urban Space and Monuments in the 'Nationalization of the Masses': the Italian Case." Pp. 171-191 in Nationalism in Europe, 1815 to the Present: a Reader, edited by S. Woolf. London: Routledge.

Togliatti, Palmiro. 1976. Lectures on Fascism. London: Lawrence and Wishart.

Toon, Ian. (2000). "Finding a Place on the Street": CCTV Surveillance and Young People's Use of Urban Public Space." Pp. 141-165 in City Visions, edited by D. Bell and A. Haddour. Harlow: Pearson Education.

Williamson, David. 1999. Mussolini: From Socialist to Fascist. London: Hodder and Stoughton.

Woolf, Stuart, ed. 1996. Nationalism in Europe, 1815 to the Present: A Reader. London: Routledge.

Woolf, Stuart. 1996. "Introduction." Pp. 1-39 in Nationalism in Europe, 1815 to the Present: a Reader, edited by S. Woolf. London: Routledge. 